\title{
SURVEI IMPLEMENTASI PELAYANAN KEBIDANAN KOMPLEMENTER DALAM MENGURANGI INTERVENSI MEDIS
}

\author{
Sifa Altika ${ }^{1}$, Uswatun Kasanah ${ }^{2}$ \\ ${ }^{1}$ staff dosen Program Studi diploma III Kebidanan Sekolah Tinggi Ilmu Kesehatan Bakti Utama Pati \\ 2,Staff Dosen Program Studi Sarjana Kebidanan Sekolah Tinggi Ilmu Kesehatan Bakti Utama Pati \\ Alamat Korespondensi: sifa.altika@gmail.com
}

\begin{abstract}
Abstrak
Terapi komplementer yang ada menjadi salah satu pilihan pengobatan masyarakat terutama bagi wanita hamil dan melahirkam. Di berbagai tempat pelayanan kesehatan tidak sedikit klien bertanya tentang terapi komplementer atau alternatif pada petugas kesehatan seperti bidan. Hal ini terjadi karena klien ingin mendapatkan pelayanan yang sesuai dengan pilihannya, sehingga apabila keinginan terpenuhi akan berdampak ada kepuasan klien. Hal ini dapat menjadi peluang bagi bidan untuk berperan memberikan terapi komplementer. Metode penelitian yang digunakan dalam penelitian ini adalah survey. dimana penelitian dilakukan tanpa melakukan intervensi terhadap subyek penelitian. Pengambilan data secara survey pada unit kerja pemberi layanan kebidanan komplementer. Populasi dalam penelitian ini seluruh bidan yang memberikan pelayanan kebidanan komplementer secara mandiri dan/atau yang bekerja pada unit pelayanan kebidanan komplementer. Dengan sampel yang digunakan secara total sampling yang di ambil dengan menggunakan teknik consecutive sampling berdasarkan waktu yang telah ditentukan. Penggunan terapi komplementer oleh Bidan paling banyak dilakukan oleh bidan adalah terapi massage/pijat yaitu sebanyak 43 bidan $(61,4 \%)$, di antaran massage yang dilakukan oleh bidan di antaranya adalah: pijat bayi, pijat nifas, pijat oksitosin, pijat payudara dan pijat perenium. Terapi komplementer lainnya yang jalankan oleh bidan yaitu hipnoterapi $(15,8 \%)$, akupresure $(12,8 \%)$, selanjutnya pelayanan yoga $(5,7 \%)$ dan obat herbal $(4,3 \%)$.
\end{abstract}

Kata Kunci: pelayanan kebidanan komplementer

\begin{abstract}
The existing complementary therapy of the community's medical options, especially for pregnant and childbirth women. In various health care providers, many clients ask questions about complementary or alternative therapies to health workers such as midwives. This happens because the client wants to get the service according to his choice, so that if the wish is fulfilled it will have an impact on client satisfaction. This can be an opportunity for midwives to play a role in providing complementary therapies. The research method used is a survey. where the research was carried out without intervening on the research subjects. Collecting data by survey at the work unit providing complementary midwifery services. The population in this study were all midwives who provide complementary midwifery services independently and / or who work in complementary midwifery service units. With the sample used in total sampling taken using consecutive sampling technique based on a predetermined time. The use of complementary therapies by midwives mostly carried out by midwives is massage / massage therapy, which is as many as 43 midwives (61.4\%), among which massages performed by midwives include: baby massage, postpartum massage, oxytocin massage, breast massage and massage. perenium. Other complementary therapies run by midwives are hypnotherapy $(15.8 \%)$, acupressure $(12.8 \%)$, then yoga services $(5.7 \%)$ and herbal medicine $(4.3 \%)$.
\end{abstract}

Keywords: complementary midwifery services

Volume 9, Nomor 1, Februari 2021 


\section{PENDAHULUAN}

Perkembangan

terapi

komplementer akhir akhir ini menjadi sorotan banyak negara. Pengobatan komplementer atau alternatif menjadi bagian penting dalam pelayanan kesehatan di Amerika Serikat dan negara lainnya (Snyder \& Lindquis, 2002). Estimasi di Amerika Serikat 627 juta orang adalah pengguna terapi alternatif dan 386 juta orang yang mengunjungi praktik konvensional (Smith et al., 2004). Data lain menyebutkan terjadi peningkatan jumlah pengguna terapi komplementer di Amerika dari 33\% pada tahun 1991 menjadi $42 \%$ di tahun 1997 (Eisenberg, 1998 dalam Snyder \& Lindquis, 2002).

Klien yang menggunakan terapi komplemeter memiliki beberapa alasan. Salah satu alasannya adalah filosofi holistik pada terapi komplementer, yaitu adanya harmoni dalam diri dan promosi kesehatan dalam terapi komplementer. Alasan lainnya karena klien ingin terlibat untuk pengambilan keputusan dalam pengobatan dan peningkatan kualitas hidup dibandingkan sebelumnya. Sejumlah $82 \%$ klien melaporkan adanya reaksi efek samping dari pengobatan konvensional yang diterima menyebabkan memilih terapi komplementer (Snyder \& Lindquis, 2002).

Gambaran dari penelitian terbaru di seluruh dunia menunjukkan bahwa di negara-negara sedang berkembang hampir $80 \%$ orang menggunakan metode terapi komplementer, terutama untuk mengobati penyakit kronis (Prass, 2012). Hal ini yang menjadikan Paradigma pelayanan kebidanan saat ini telah mengalami pergeseran. asuhan kebidanan dilaksanakan dengan mengkombinasikan pelayanan kebidanan konvensional dan komplementer, serta telah menjadi bagian penting dari praktek kebidanan (Harding \& Foureur, 2009). Di Indonesia, beberapa metode seperti jamu-jamuan telah digunakan selama ribuan tahun dan berkembang pesat. Perempuan lebih banyak menggunakan pengobatan komplementer dan alternatif, terutama selama kehamilan dan persalinan karena lebih sedikit efek samping dibandingkan dengan obatobatan kimia. Saat ini, di seluruh dunia, lebih banyak bidan menggunakan terapi komplementer dalam profesi mereka dibandingkan praktisi medis lainnya. Bidan biasanya menggunakan satu atau lebih terapi komplementer seperti terapi pijat, obat-obatan herbal, teknik relaksasi, yoga, senam, suplemen nutrisi, aromaterapi, homeopati dan akupunktur. Mengingat meluasnya penggunaan pengobatan komplementer dan alternatif di bidang kebidanan, organisasi medis juga perlu mempersiapkan pedoman relevan untuk menggunakan pengobatan tersebut dalam praktik kebidanan, terutama untuk perawatan bersalin.

Terapi komplementer yang ada menjadi salah satu pilihan pengobatan masyarakat terutama bagi wanita hamil dan melahirkam. Di berbagai tempat pelayanan kesehatan tidak sedikit klien bertanya tentang terapi komplementer atau alternatif pada petugas kesehatan seperti bidan. Hal ini terjadi karena klien ingin mendapatkan pelayanan yang sesuai dengan pilihannya, sehingga apabila keinginan terpenuhi akan berdampak ada kepuasan klien. Hal ini dapat menjadi peluang bagi bidan untuk berperan memberikan terapi komplementer.

Di Indonesia belum ada UndangUndang yang mengatur secara khusus tentang pelaksanaan pelayanan kebidanan komplementer, namun penyelenggaraan pengobatan 
komplementer secara umum telah diatur dalam Keputusan Menteri Kesehatan No.1109/Menkes/Per/IX/2007 tentang pengobatan komplementer-alternatif. Bagi banyak bidan dan wanita, pelayanan kebidanan komplementer adalah pilihan untuk mengurangi intervensi medis saat hamil dan melahirkan, dan berdasarkan pengalaman hal tersebut cukup membantu. Namun, sebagian besar terapi ini tidak dianggap bermakna dalam pengobatan konvensional. (Ernst\&Watson, 2012).

Peran yang dapat diberikan bidan dalam terapi komplementer atau alternatif dapat disesuaikan dengan peran perawat yang ada, sesuai dengan batas kemampuannya. Pada dasarnya, perkembangan bidan yang memerhatikan hal ini sudah ada. Kebutuhan masyarakat yang meningkat dan berkembangnya penelitian terhadap terapi komplementer menjadi peluang bidan untuk berpartisipasi sesuai kebutuhan masyarakat. Bidan dapat berperan sebagai konsultan untuk klien dalam memilih alternatif yang sesuai ataupun membantu memberikan terapi langsung. Namun, hal ini perlu dikembangkan lebih lanjut melalui penelitian (evidence-based practice) agar dapat dimanfaatkan sebagai terapi kebidanan yang lebih baik.

Berdasarkan dari permasalahan itu maka peneliti memutuskan untuk melakukan penelitian tentang "implementasi pelayanan kebidanan komplementer dalam mengurangi intervensi medis saat hamil dan melahirkan"

\section{METODE PENELITIAN}

Metode penelitian yang digunakan dalam penelitian ini adalah survey. dimana penelitian dilakukan tanpa melakukan intervensi terhadap subyek penelitian. Pengambilan data secara survey pada unit kerja pemberi layanan kebidanan komplementer dilakukan pada bulan Januari-Maret.

Survey dilakukan dalam dua tahap, tahap pertama dengan membagikan kuesioner/ angket yang berisi beberapa pertanyaan terkait pelaksanaan pelayanan kebidanan komplementer, dan dilengkapi dengan pertanyaan mengenai karakteristik responden. Pelayanan kebidanan komplementer yang dimaksud adalah pelayanan kesehatan yang diberikan oleh bidan yang telah terdaftar yang dapat dilakukan secara mandiri kepada ibu hamil, ibu bersalin, ibu nifas, bayi baru lahir, bayi dan anak, serta wanita usia reproduksi dan usia lanjut, dengan menerapkan pengobatan non konvensional (alternatif dan tradisional) yang ditujukan untuk mendukung keadaan normal klien atau sebagai pilihan alternatif

dalam mengatasi penyulit ataupun komplikasi.

Setelah data kuesioner didapat, maka dilakukan analisis data sementara, kemudian peneliti menentukan responden yang akan diwawancara secara mendalam untuk melengkapi data sesuai tujuan penelitian. Wawancara mendalam dilakukan secara langsung oleh peneliti baik mendatangi langsung ke kediamannya maupun wawancara melalui telepon untuk mengekplorasi dan memperluas informasi terpendam dengan menggunakan pertanyaan terbuka (Sugiyono, 2010).

Subyek dalam penelitian ini adalah bidan yang memberikan pelayanan kebidanan komplementer secara mandiri dan/atau yang bekerja pada unit pelayanan kebidanan komplementer. Subyek penelitian terdiri atas populasi dan sampel. Populasi dalam penelitian ini seluruh bidan yang memberikan pelayanan kebidanan komplementer 
secara mandiri dan/atau yang bekerja pada unit pelayanan kebidanan komplementer. Dengan sampel yang digunakan secara total sampling yang di ambil dengan menggunakan teknik consecutive sampling berdasarkan waktu yang telah ditentukan.

Alat ukur dalam penelitian ini menggunakan kuesioner yang telah dibuat oleh peneliti sendiri. Kuesioner akan di bagikan kepada responden/ klien/pasien. Pertanyaan yang telah diberikan berupa pertanyaan tertutup dan dijawab langsung oleh responden tanpa diwakilkan kepada orang namun jika ibu tidak bias membaca maka akan dibantu oleh peneliti dalam penelitiannya. Pengumpulan data pada penelitian ini dilakukan dengan menggunakan angket/kuesioner dan observasi secara langsung.

Data hasil penelitian disajikan dalam bentuk distribusi frekuensi kuotasi hasil wawancara, Penyajian hasil dalam bentuk distribusi frekuensi merupakan bagian dari penelitian deskriptif kuantitatif. Sedangkan penyajian data hasil penelitian dalam bentuk kuotasi merupakan bagian dari penelitian deskriptif kualitatif.

Data hasil penelitian disajikan dalam bentuk distribusi frekuensi dan kuotasi hasil wawancara. Penyajian hasil dalam bentuk distribusi frekuensi merupakan bagian dari penelitian deskriptif kuantitatif. Sedangkan penyajian data hasil penelitian dalam bentuk kuotasi merupakan bagian dari penelitiann deskriptif kualitatif.

\section{HASIL PENELITIAN}

Tabel 1 .

Jenis Pelayanan Kebidanan Komplementer yang di Praktikkan oleh Bidan

\begin{tabular}{llll}
\hline No. & Pelayanan kebidanan komplementer & Jumlah (n) & Persentase (\%) \\
\hline 1 & Pijat/ massage & 43 & $61,4 \%$ \\
\hline 2 & Akupresure & 9 & $12,8 \%$ \\
\hline 3 & Hipnoterapi & 11 & $15,8 \%$ \\
\hline 4 & Obat herbal & 3 & $4,3 \%$ \\
\hline 5 & Yoga & 4 & $5,7 \%$ \\
\hline & Jumlah & 70 & $100 \%$ \\
\hline
\end{tabular}

Tabel 1 menunjukkan bahwa Pelayanan kebidanan komplementer yang dijalankan oleh bidan sebanyak 70 bidan, pdengan pelayanan kebidanan komplementer pada jenis pijat/massage $(61,4 \%)$ yaitu 43 bidan. Dilanjut dengan hipnoterapi (15,8\%), akupresure $(12,8 \%)$, selanjutnya pelayanan yoga $(5,7 \%)$ dan obat herbal $(4,3 \%)$.

\section{PEMBAHASAN}

Terapi komplementer dikenal dengan terapi tradisional yang digabungkan dalam pengobatan modern. Komplementer adalah penggunaan terapi tradisional ke dalam pengobatan modern (Andrews et al., 1999). Terminologi ini dikenal sebagai terapi modalitas atau aktivitas yang menambahkan pendekatan ortodoks dalam pelayanan kesehatan (Crips \& Taylor, 2001). Terapi komplementer juga ada yang menyebutnya dengan pengobatan holistik. Pendapat ini didasari oleh bentuk terapi yang mempengaruhi individu secara menyeluruh yaitu sebuah keharmonisan individu untuk mengintegrasikan pikiran, badan, dan jiwa dalam kesatuan fungsi (Smith et al., 2004).

Berdasarkan hasil penelitian Pelayanan kebidanan komplementer yang dijalankan oleh bidan sebanyak 70 bidan, pdengan pelayanan kebidanan 
komplementer pada jenis pijat/massage $(61,4 \%)$ yaitu 43 bidan. Dilanjut dengan hipnoterapi (15,8\%), akupresure $(12,8 \%)$, selanjutnya pelayanan yoga $(5,7 \%)$ dan obat herbal $(4,3 \%)$.

Hasil penelitian Koc Z (2012) di Turki, menyebutkan bahwa $58.9 \%$ dari 129 bidan yang bekerja pada pusat kesehatan keluarga wilayah Samsun memberikan pengobatan alternatif dan komplementer pada pasiennya terutama ibu hamil. Pengobatan dan terapi komplementer telah diatur dalam PERMENKES No: 1109/ Menkes/Per/IX/2007. Adapun jenisjenis terapi komplementer antara lain:

a. Intervensi tubuh dan pikiran (mind and body interventions) meliputi : Hipnoterapi, mediasi, penyembuhan spiritual, doa dan yoga.

b. Sistem pelayanan pengobatan alternatif meliputi: akupuntur, akupresur, naturopati, homeopati, aromaterapi, Ayurveda

c. Cara penyembuhan manual meliputi: chiropractice, healing touch, tuina, shiatsu, osteopati, pijat urut

d. Pengobatan farmakologi dan biologi meliputi: jamu, herbal, gurah

e. Diet dan nutrisi untuk pencegahan dan pengobatan meliputi: diet makro nutrient, mikro nutrient

f. Cara lain dalam diagnosa dan pengobatan meliputi: terapi ozon, hiperbarik.

Berdasarkan peraturan menteri kesehatan RI tentang jenis-jenis terapi komplementer yang telah diakui di Indonesia yang tersebut di atas, sebenarnya setiap tenaga kesehatan mempunyai perlindungan hukum untuk dapat memberikan pelayanan kesehatan menggunakan terapi komplementer sesuai dengan lingkup pelayanan berdasarkan profesinya. Dalam pelayanan kebidanan, hampir semua yang tersebut di atas dapat diaplikasikan oleh bidan pada ibu dan anak.
Jenis massage yang diterapkan oleh bidan dalam pelayanan komplementer meliputi:

a. Pijat Oksitosin: Pijat oksitosin merupakan pemijatan tulang belakang pada costa ke 5-6 sampai ke scapula yang akan mempercepat kerja saraf parasimpatis merangsang hipofise posterior untuk mengeluarkan oksitosin (Hashimoto, 2014)

b. Pijat Nifas: Pijat ini umumnya dilakukan bidan pada minggu pertama hingga minggu kedua setelah persalinan ibu nifas. Hasil wawancara menjelaskan bahwa tujuan dari dilakukannya perawatan nifas (spa nifas) dengan melakukan pemijatan (massage) adalah untuk melancarkan aliran darah dan meningkatkan kenyamanan ibu nifas.

c. Pijat Bayi : Beberapa bidan menerima pemijatan bayi dalam rangkaian perawatan baby spa. Hasil pemaparan bidan menjelaskan bahwa dengan pijat bayi, akan membuat bayi tidak 'rewel' dan meningkatkan nafsu makan. Usia bayi yang dipijat bervariasi, rentang 0-12 bulan.

d. Massage Payudara: Massage payudara yang dimaksud dalam penelitian ini adalah pemijatan payudara pada masa nifas. Bidan yang memberikan perawatan ini, melakukannya bersamaan dengan postnatal treatment. Pemaparan bidan menjelaskan bahwa pemijatan dilakukan dengan lembut, bertujuan untuk memperlancar produksi ASI.

e. Massage Perineum: Massage perineum merupakan pijatan atau penguluran (stretching) lembut yang dilakukan pada area perineum (kulit di antara anus dan vagina). Pijat perineum bertujuan untuk meningkatkan elastisitas perineum. Peningkatan elastisitas perineum akan mencegah kejadian robekan 
perineum pada saat persalinan normal maupun pada episiotomi

\section{KESIMPULAN DAN SARAN}

Penggunan terapi komplementer oleh Bidan paling banyak dilakukan oleh bidan adalah terapi massage/pijat yaitu sebanyak 43 bidan $(61,4 \%)$, di antaran massage yang dilakukan oleh bidan di antaranya adalah: pijat bayi, pijat nifas, pijat oksitosin, pijat payudara dan pijat perenium. Terapi komplementer lainnya yang jalankan oleh bidan yaitu hipnoterapi $(15,8 \%)$, akupresure $\quad(12,8 \%), \quad$ selanjutnya pelayanan yoga $(5,7 \%)$ dan obat herbal $(4,3 \%)$.

Upaya yang dapat dilakukan untuk meningkatkan cakupan pemberian pelayanan kebidanan komplementer yaitu: setiap tenaga kesehatan dan masyarakat menggunakan dan mengembangkan terapi komplementer, perlu adanya penelitian lebih lanjut mengenai dan alternatif, perlu dukungan penuh dari organisasi profesi dan pemerintah dalam bentuk memfasilitasi tenaga kesehatan dalam penyelenggaraan pendidikan dan pelatihan tentang penggunaan terapi komplementer, perlu adanya upaya sosialisasi dan promosi kepada masyarakat tentang manfaat penggunaan terapi komplementer dan alternatif sebagai pelengkap pemberian layanan medis, dan memberdayakan bidan sebagai fasilitator bagi masyarakat untuk meningkatkan upaya promotif dan preventif melalui terapi komplementer.

DAFTAR PUSTAKA

Andrews, M., Angone, K.M., Cray, J.V., Lewis, J.A., \& Johnson, P.H. (1999). Nurse's handbook of alternative and complementary therapies. Pennsylvania: Springhouse.

Ernst, Edzard \& Watson, Leala. 2012. Midwives' use of complementary/ Alternative Treatments: Midwifery Journal, Volume 28, Issue 6, Ed: December 2012, Pages 772777.

Fontaine, K.L. (2005). Complementary $\&$ alternative therapies for nursing practice. 2th ed. New Jersey: Pearson Prentice Hall

Harding, Debble \& Foureur, Maralyn. 2009. New Zaeland and Canadian Midwifes' Use of Complementary and Alternative Therapy: New Zaeland College of Midwives, Journal 40, Ed: April 2009.

Hitchcock, J.E, Schubert, P.E., Thomas, S.A. (1999). Community health nursing: Caring in action. USA: Delmar Publisher

Keputusan Menteri Kesehatan Republik Indonesia Nomor 1109/Menkes/Per/IX/2007 tentang penyelenggaraan pengobatan komplementeralternatif.

Nezabudkin, V. (2007). How to research alternative treatment before using them.http//.www.naturalhealthw eb.com/art icles/ Nezabudkin1.html, diperoleh 25 Januari 2008.

Smith, S.F., Duell, D.J., Martin, B.C. (2004). Clinical nursing skills: Basic to advanced skills. New Jersey: Pearson Prentice Hall.

Snyder, M. \& Lindquist, R. (2002).Complementary/alternati ve therapies in nursing. 4th ed. New York: Springer.

Sugiyono. 2010. Metode Penelitian Kualitatif dan R\&D. Bandung: CV.Alfabeta. 